\title{
Fatty Acid Profile of Sunflower Achene Oil From the Brazilian Semi-arid Region
}

\author{
Claudio G. P. de Carvalho ${ }^{1}$, Andressa Caldeira ${ }^{2}$, Luciana M. de Carvalho ${ }^{3}$, Hélio W. L. de Carvalho ${ }^{3}$, \\ José L. Ribeiro ${ }^{4}$, José M. G. Mandarino ${ }^{1}$, José C. F. de Resende ${ }^{5}$, Ariomar R. dos Santos ${ }^{6}$, \\ Marcos R. da Silva ${ }^{7} \&$ Nair H. C. Arriel $^{8}$ \\ ${ }^{1}$ Embrapa Soja, Londrina, PR, Brazil \\ ${ }^{2}$ Universidade Norte do Paraná, Londrina, PR, Brazil \\ ${ }^{3}$ Embrapa Tabuleiros Costeiros, Aracaju, SE, Brazil \\ ${ }^{4}$ Embrapa Meio-Norte, Teresina, PI, Brazil \\ ${ }^{5}$ Empresa de Pesquisa Agropecuária de Minas Gerais, Montes Claros, MG, Brazil \\ ${ }^{6}$ Instituto Federal de Educação, Ciência e Tecnologia Baiano, Bom Jesus da Lapa, BA, Brazil \\ ${ }^{7}$ Universidade Federal do Recôncavo da Bahia, Cruz das Almas, BA, Brazil \\ ${ }^{8}$ Embrapa Algodão, Campina Grande, PB, Brazil \\ Correspondence: Claudio G. P. de Carvalho, Embrapa Soja, Caixa Postal 231, CEP: 86001-970, Londrina, PR, \\ Brazil. Tel: 55-43-3371-6234. E-mail: portela.carvalho@embrapa.br
}

$\begin{array}{lcc}\text { Received: June 15, } 2018 & \text { Accepted: July 18, } 2018 & \text { Online Published: September 15, } 2018 \\ \text { doi:10.5539/jas.v10n10p144 } & \text { URL: https://doi.org/10.5539/jas.v10n10p144 }\end{array}$

\begin{abstract}
The analysis of the fatty acid profile of an oil is important for optimizing its use in the processing and food industries. The present work evaluated the fatty acid profile from sunflower achene oil grown in the Brazilian semi-arid region and adjacent regions. The oleic, linoleic, palmitic and stearic acid contents were determined by gas chromatography (GC). An approximate $5{ }^{\circ} \mathrm{C}$ increase (from $19{ }^{\circ} \mathrm{C}$ to $24{ }^{\circ} \mathrm{C}$ ) in the minimum temperature during lipid fraction (oil) formation in achenes yielded a $22.6 \%$ increase and a $21.9 \%$ decrease in the average oleic acid and linoleic acid contents $(41.0 \%$ to $63.5 \%$ and $50.9 \%$ to $29.0 \%$, respectively). The saturated fatty acids content tended to decrease as the minimum temperature increased, although the behavior depended on the environment and the tested genotypes. In general, genotypes Aguara 04 and CF 101 presented higher oleic acid and lower linoleic, palmitic and stearic acid contents than did the HELIO 250 and HELIO 251 genotypes.
\end{abstract}

Keywords: Helianthus annuus, linoleic acid, oleic acid, saturated fatty acids

\section{Introduction}

The Brazilian semi-arid region is located in the Southeastern and, especially, in the Northeastern regions of Brazil, occupying an area of $980,133 \mathrm{~km}^{2}$. The region is characterized by high mean temperatures (approximately $26^{\circ} \mathrm{C}$ ), which exert a strong effect on evapotranspiration, causing water deficits throughout most of the year, which in turn pose significant limitations for sustainable agricultural development (Lacerda et al., 2015). Among the possible consequences of global climate change, the scenario in the Brazilian semi-arid region may deteriorate by becoming an Arid region, while adjacent regions may acquire semi-arid features (Marengo et al., 2010).

Alternative crops are fundamental for the economic development of this region. Sunflower (Helianthus annuus L.), with its good tolerance to water stress and heat, may become an important alternative. Excellent quality oil can be extracted from sunflower achenes, mainly for use in the food industry, human consumption (in the refined form) and fish feeds (Nasopoulou \& Zabetakis, 2012; Grunvald et al., 2013).

Oil quality is associated with its fatty acid profile. Linoleic and oleic acids constitute approximately $90 \%$ of the total fatty acids in sunflower achene oil (Van der Merwe, Labuschagne, Herselman, \& Hugo, 2013). The former promotes a reduction in low-density lipoproteins (LDL cholesterol), contributing to a reduction in the risk of cardiovascular diseases (Farvid et al., 2014). The latter may have the same health benefits provided by linoleic 
acid and may also contribute to the oil's higher degree of oxidative stability during the extraction and refining process and during storage and use (e.g., in frying) (Miller, Zimmerman, \& Vick, 1987; Perdomo et al., 2015). Thus, the consumption of sunflower oil with higher oleic acid contents has increased (Vannozzi et al., 2006).

There is an inverse relationship between oleic acid and linoleic acid contents, which can be influenced by environmental conditions, particularly by the minimum temperature during the oil synthesis stages in achenes (Harris, McWilliam, \& Mason, 1978; Lajara, Díaz, \& Quidiello, 1990; Grunvald et al., 2013; Neto, Miguel, Mourad, Henriques, \& Alves, 2016; Carvalho et al., 2018). In warmer regions, there was a tendency to produce oils with higher oleic acid contents.

Palmitic and stearic acids exhibit the highest levels in the remaining fatty acid fraction (approx. 10\%) of sunflower oil; both fatty acids are extremely important when the oil is used in the chemical and cosmetic industries. Discordant results have been obtained in relation to the effects of minimum temperature on these saturated fatty acids (Izquierdo \& Aguirrezábal, 2008; Grunvald et al., 2013).

Although the Brazilian semi-arid region is considered a warm region, the minimum temperatures vary with the location, and oils with different fatty acid profiles can be obtained depending on the cultivation site. As the analysis of the quality of an oil is important for optimizing its use in the processing and food industries, the present work aimed to evaluate the fatty acid profile of sunflower achene oil grown in the Brazilian semi-arid and adjacent regions.

\section{Material and Methods}

\subsection{Field Experiments}

Sunflower achene production experiments were conducted between the 2014 and 2016 harvests at latitudes between $3^{\circ} \mathrm{S}$ (Magalhães de Almeida and Mata Roma, in Maranhão) and $15^{\circ} \mathrm{S}$ (Jaíba, Minas Gerais); these latitudes were thus chosen to represent the environmental variability in the semi-arid region and to cover larger minimum temperature differences during achene formation that may yield different oil fatty acid profiles, according to some authors (Izquierdo \& Aguirrezábal, 2008; Grunvald et al., 2013; Carvalho et al., 2018). With the exception of Mata Roma (MA), Magalhães de Almeida (MA), Teresina (PI) and Cruz das Almas (BA), all sites are located in the Brazilian semi-arid region. The geographical coordinates and minimum temperatures (average daily minima) of each site during the achene maturation phase, and the respective responsible research institutions are described in Table 1.

The experiment followed a completely randomized block design, with four replicates, each plot consisting of four $6.0-\mathrm{m}$-long rows spaced $0.7 \mathrm{~m}$ apart. At harvest, the two external rows and $0.5 \mathrm{~m}$ of each end of the central rows were discarded as borders, resulting in a useful plot area of $7.0 \mathrm{~m}^{2}$.

Fertilization done during the sowing consisted of $25 \mathrm{~kg} \mathrm{ha}^{-1}$ of $\mathrm{N}, 75 \mathrm{~kg} \mathrm{ha}^{-1}$ of $\mathrm{P}_{2} \mathrm{O}_{5}$ and $75 \mathrm{~kg} \mathrm{ha}^{-1}$ of $\mathrm{K}_{2} \mathrm{O}$ distributed in the seeding rows according to Leite, Brighenti, \& de Castro (2005). Cover fertilization occurred 35 days after sowing, applying $45 \mathrm{~kg} \mathrm{ha}^{-1}$ of $\mathrm{N}$ and $2.0 \mathrm{~kg} \mathrm{ha}^{-1}$ of B. Sowing was done manually at $0.04 \mathrm{~m}$ depth, with three seeds per hole, an uniform population and expected density of 45,000 plants ha ${ }^{-1}$. Thinning was performed seven days after seedling emergence, with one plant per hole.

The evaluated genotypes were Aguara 04, Aguará 06, BRS 323, CF 101, HELIO 250 and HELIO 251-all six hybrids from different breeding programs with good productive performance in a semi-arid region (Carvalho, Carvalho, Carvalho, Marques, \& Porto, 2016).

\subsection{Fatty Acid Profile}

The oleic $\left(\mathrm{C} 18: 1 \Delta^{9}\right)$, linoleic $\left(\mathrm{C} 18: 2 \Delta^{9,12}\right)$, palmitic $(\mathrm{C} 16: 0)$ and stearic $(\mathrm{C} 18: 0)$ acid contents in oil extracted from the achenes of different sunflower genotypes were determined by gas chromatography (GC), following the methodology established by the American Oil Chemists' Society (Firestone, 2013).

For the extraction of the fatty acids, achene samples were ground in a micro mill. Then, $200 \mathrm{mg}$ of ground sample was transferred to 50 -mL, screw-cap, conical Falcon tubes, to which $5.0 \mathrm{~mL}$ of freshly prepared $1 \%$ sodium methoxide $\left(\mathrm{CH}_{3} \mathrm{ONa}\right)$ solution was added. The tubes were homogenized in a vortex mixer and allowed to stand for 1 hour at room temperature to allow the esterification reaction to occur; during this period, the tubes were shaken every 15 minutes in a vortex mixer. Subsequently, $1.0 \mathrm{~mL}$ of $10 \%$ glacial acetic acid was added, followed by homogenization in a vortex mixer. Next, $5.0 \mathrm{~mL}$ of HPLC-grade heptane were added, and the tubes were again homogenized. A 2.0-ml aliquot of the heptane layer was transferred into injection vials for gas chromatography analysis. 
The fatty acid profile determination and quantification were performed on a Hewlett Packard model 6890 gas chromatograph equipped with an automatic sample injector. Two $1.0-\mu \mathrm{L}$ injections of each sample were performed, with split rates ranging from 5:1 to 40:1, depending on sample concentration. The temperatures of the injector and the flame ionization detector (FID) were set to $250{ }^{\circ} \mathrm{C}$ and $300^{\circ} \mathrm{C}$, respectively. The fatty acids were separated using a silica capillary column (Supelco, model SP 2340) with the following dimensions: $30 \mathrm{~m}$ length, $0.3 \mathrm{~mm}$ internal diameter and $0.2 \mu \mathrm{m}$ film thickness. The column temperature was adjusted to $190{ }^{\circ} \mathrm{C}$, and the separation occurred isothermally. The fatty acid profile and contents were determined using an external standard: fatty acid methyl ester standards (Sigma).

Table 1. Geographic coordinates and minimum temperatures of the experimental sites between 2014 and 2016 in the Brazilian semi-arid region

\begin{tabular}{|c|c|c|c|c|c|c|c|}
\hline \multirow{2}{*}{ State } & \multirow{2}{*}{ City } & \multirow{2}{*}{ Year } & \multirow{2}{*}{ Institution } & \multicolumn{3}{|c|}{ Geographic coordinates } & \multirow{2}{*}{$\begin{array}{l}\text { Minimum air } \\
\text { temperature }\left({ }^{\circ} \mathrm{C}\right)^{1}\end{array}$} \\
\hline & & & & Altitude (m) & Latitude & Longitude & \\
\hline \multirow[t]{2}{*}{ Bahia } & Bom Jesus da Lapa & 2013 & IF Baiano & 483 & $13^{\circ} 15^{\prime} 18^{\prime \prime} \mathrm{S}$ & $43^{\circ} 25^{\prime} 05^{\prime \prime} \mathrm{W}$ & 21.8 \\
\hline & Cruz das Almas & 2015 & UFRB & 220 & $12^{\circ} 40^{\prime} 12^{\prime \prime} \mathrm{S}$ & $39^{\circ} 06^{\prime} 07^{\prime \prime} \mathrm{W}$ & 19.2 \\
\hline \multirow[t]{2}{*}{ Maranhão } & Magalhães de Almeida & 2014 & Embrapa & 36 & $03^{\circ} 23^{\prime} 46^{\prime \prime} \mathrm{S}$ & $42^{\circ} 12^{\prime} 14^{\prime \prime} \mathrm{W}$ & 23.0 \\
\hline & Mata Roma & 2014 & Embrapa & 73 & $03^{\circ} 37^{\prime} 30^{\prime \prime} \mathrm{S}$ & $43^{\circ} 06^{\prime} 40^{\prime \prime} \mathrm{W}$ & 26.0 \\
\hline \multirow[t]{2}{*}{ Piauí } & São João do Piauí & 2014 & Embrapa & 222 & $08^{\circ} 21^{\prime} 29^{\prime \prime} \mathrm{S}$ & $42^{\circ} 14^{\prime} 48^{\prime \prime} \mathrm{W}$ & 22.5 \\
\hline & Teresina & 2015 & Embrapa & 72 & $05^{\circ} 05^{\prime} 21^{\prime \prime} \mathrm{S}$ & $42^{\circ} 48^{\prime} 07^{\prime \prime} \mathrm{W}$ & 23.2 \\
\hline \multirow[t]{2}{*}{ Sergipe } & Frei Paulo & 2014 & Embrapa & 272 & $10^{\circ} 32^{\prime} 58^{\prime \prime} \mathrm{S}$ & $37^{\circ} 32^{\prime} 04^{\prime \prime} \mathrm{W}$ & 18.8 \\
\hline & Poço Redondo & 2014 & Embrapa & 188 & $09^{\circ} 48^{\prime} 18^{\prime \prime} \mathrm{S}$ & $37^{\circ} 41^{\prime} 04^{\prime \prime} \mathrm{W}$ & 19.5 \\
\hline Minas Gerais & Jaíba & 2015 & EPAMIG & 470 & $15^{\circ} 20^{\prime} 18^{\prime \prime} \mathrm{S}$ & $43^{\circ} 40^{\prime} 28^{\prime \prime} \mathrm{W}$ & 21.5 \\
\hline Paraíba & Alagoa Nova & 2016 & Embrapa & 530 & $07^{\circ} 13^{\prime} 50^{\prime \prime} \mathrm{S}$ & $35^{\circ} 52^{\prime} 52^{\prime \prime} \mathrm{W}$ & 21.0 \\
\hline
\end{tabular}

Note. ${ }^{1}$ Average minimum temperature observed during the sunflower achene maturation period.

\subsection{Statistical Analysis}

Analysis of variance was performed for the oleic, linoleic, palmitic and stearic acid contents, considering the data obtained for each site and each year (environment). A combined analysis of variance was performed for environments since the cultivation sites differed from one year to another. Homogeneity of residual variance in each environment analysis was previously assessed (Gomes, 1985). Genotype comparison was performed using Tukey's test at 5\% probability. SISVAR statistical software (Ferreira, 2001) was employed for the analyses.

\section{Results and Discussion}

\subsection{Oleic and Linoleic Acids}

The differences in oleic and linoleic acid contents between the different genotypes, environments and genotype $\times$ environment interactions were significant by the $F$-test $(\mathrm{P}<0.01)$, indicating that the difference between genotypes should be analyzed in each environment (specific site and year), and the environmental effect should be evaluated for each genotype (Table 2).

Table 2. Combined analysis of variance for oleic $\left(\mathrm{C} 18: 1 \Delta^{9}\right)$, linoleic $\left(\mathrm{C} 18: 2 \Delta^{9,12}\right)$, stearic (C18:0) and palmitic (C16:0) acid contents in sunflower achene oil obtained from experiments conducted in the Brazilian semi-arid region

\begin{tabular}{|c|c|c|c|c|c|}
\hline \multirow{2}{*}{ Source of Variation } & \multirow{2}{*}{ df } & \multicolumn{4}{|c|}{ Mean squared } \\
\hline & & $\mathrm{C} 18: 1 \Delta^{9}$ & $\mathrm{C} 18: 2 \Delta^{9,12}$ & C18:0 & C16:0 \\
\hline Blocks/Environment & 30 & 3.3167 & 3.7681 & 0.0757 & 0.0170 \\
\hline Genotype (G) & 5 & $464.1196^{* *}$ & $414.2676^{* *}$ & $1.4700 * *$ & $3.1506^{* *}$ \\
\hline Environment (E) & 9 & $2305.6974 * *$ & $2169.1707^{* *}$ & $1.1863 * *$ & $3.9045 * *$ \\
\hline $\mathrm{G} \times \mathrm{E}$ & 45 & $53.0936 * *$ & $47.1038 * *$ & $0.1948 * *$ & $0.1682 * *$ \\
\hline Error & 149 & 2.2166 & 2.1710 & 0.0473 & 0.0220 \\
\hline Mean & & 53.54 & 38.61 & 3.23 & 4.24 \\
\hline $\mathrm{CV}(\%)$ & & 2.78 & 3.82 & 6.72 & 3.50 \\
\hline
\end{tabular}

Note. ** Significant at $1 \%$ probability by $F$-test. 
The oleic acid contents varied between 30.4\% (HELIO 250 in Cruz das Almas, 2015) and 71.8\% (Aguará 6 in Magalhães de Almeida, 2014), while the linoleic acid contents varied between 21.0\% (Aguará 6 in Magalhães de Almeida, 2014) and 58.2\% (Aguará 6 in Alagoa Nova, 2016) (Table 3). Higher oleic acid contents were found in environments with higher minimum temperatures (above $23{ }^{\circ} \mathrm{C}$ ) during achene formation: Mata Roma (2014), Teresina (2015) and Magalhães de Almeida (2014). In contrast, the highest linoleic acid contents were obtained in places with lower minimum temperatures (below $21^{\circ} \mathrm{C}$ ) during oil synthesis in achenes: Frei Paulo (2014), Cruz da Almas (2015), and Alagoa Nova (2016). Similar oleic and linoleic acid contents in sunflower achene oil as a function of the minimum temperature during oil synthesis were also reported by Harris et al. (1978), Lajara et al. (1990), Grunvald et al. (2013), Neto et al. (2016).

One of the reasons ascribed to the association between the fatty acid composition and the minimum temperature is the effect of temperature on oleate desaturase activity. Higher minimum temperatures affect the activity of this enzyme, which is responsible for the conversion of oleic to linoleic acid (Canvin, 1965; Flagella, Rotunno, Tarantino, Caterina, \& Caro, 2002). In studies conducted in Australia (Harris et al., 1978) and Spain (Lajara et al., 1990), an increase of $1{ }^{\circ} \mathrm{C}$ in the minimum temperature increased the content of oleic acid in sunflower achene oil by up to $2 \%$. In Argentina (Izquierdo \& Aguirrezábal, 2008) and the tropical region of Brazil (Grunvald et al., 2013), a $1{ }^{\circ} \mathrm{C}$ increase in the minimum temperature yielded an approximate $3.5 \%$ increase in oleic acid content. In the Brazilian semi-arid and adjacent regions (Table 3), environments with a minimum temperature close to $19{ }^{\circ} \mathrm{C}$ (Frei Paulo, 2014; Cruz das Almas, 2014) had average oleic and linoleic acid contents of $40.95 \%$ and $50.9 \%$, respectively, whereas environments where the minimum temperature was equal to or above $23{ }^{\circ} \mathrm{C}$ (Mata Roma, 2014, Teresina, 2015 and Magalhães de Almeida, 2014) showed average oleic and linoleic acid contents of $63.5 \%$ and $29.0 \%$, respectively. Thus, an average minimum temperature increase of $5{ }^{\circ} \mathrm{C}$ during oil synthesis in achenes in these environments yielded a $22.6 \%$ increase in the average oleic acid content $(41.0 \%$ to $63.5 \%)$ and an average $21.9 \%$ decrease in linoleic acid content $(50.9 \%$ to $29.0 \%)$. These findings indicate that the minimum temperature influenced the sunflower achene oil fatty acid profiles in these environments, with the degree of influence depending on the growing environment.

Table 3. Oleic $\left(\mathrm{C} 18: 1 \Delta^{9}\right)$ and linoleic $\left(\mathrm{C} 18: 2 \Delta^{9,12}\right)$ acid contents of sunflower achene oil obtained from experiments conducted in the Brazilian semi-arid region

\begin{tabular}{|c|c|c|c|c|c|c|c|c|c|c|c|}
\hline $\begin{array}{l}\text { Genotype/ } \\
\text { Environment }\end{array}$ & Mean & $\begin{array}{l}\text { Frei } \\
\text { Paulo } \\
(\mathrm{SE}) \\
2015\end{array}$ & $\begin{array}{l}\text { Cruz das } \\
\text { Almas } \\
\text { (BA) } \\
2015\end{array}$ & $\begin{array}{l}\text { Poço } \\
\text { Redondo } \\
\text { (SE) } \\
2014\end{array}$ & $\begin{array}{l}\text { Alagoa } \\
\text { Nova } \\
(\mathrm{PB}) \\
2016\end{array}$ & $\begin{array}{l}\text { Jaíba } \\
(\mathrm{MG}) \\
2015\end{array}$ & $\begin{array}{l}\text { Bom Jesus } \\
\text { da Lapa } \\
\text { (BA) } \\
2014\end{array}$ & $\begin{array}{l}\text { São João } \\
\text { do Piauí } \\
\text { (PI) } \\
2014\end{array}$ & $\begin{array}{l}\text { Magalhães } \\
\text { de Almeida } \\
\text { (MA) } \\
(2014)\end{array}$ & $\begin{array}{l}\text { Teresina } \\
(\mathrm{PI}) \\
2015\end{array}$ & $\begin{array}{l}\text { Mata } \\
\text { Roma } \\
\text { (MA) } \\
2014\end{array}$ \\
\hline \multicolumn{12}{|l|}{ C18:1 $\Delta^{9}(\%)$} \\
\hline Aguara 04 & 54.9 & $41.5 \mathrm{cE}^{1}$ & $41.2 \mathrm{aE}$ & $60.3 \mathrm{bB}$ & $48.8 \mathrm{aD}$ & $57.2 \mathrm{bB}$ & $57.5^{2 /} \mathrm{bB}$ & $52.6 \mathrm{abC}$ & $69.4 \mathrm{aA}$ & $52.7 \mathrm{cC}$ & $67.5 \mathrm{aA}$ \\
\hline Aguará 06 & 55.9 & $44.8 \mathrm{bF}$ & $40.4 \mathrm{abG}$ & $59.5 \mathrm{bCD}$ & $32.9 \mathrm{cH}$ & $60.7 \mathrm{aC}$ & $57.1 \mathrm{bDE}$ & $54.3 \mathrm{aE}$ & $71.8 \mathrm{aA}$ & $67.4 \mathrm{aB}$ & $69.9 \mathrm{aAB}$ \\
\hline BRS 323 & 56.8 & $49.5 \mathrm{aE}$ & $37.9 \mathrm{bcF}$ & $63.4 \mathrm{aBC}$ & $50.6 \mathrm{aE}$ & $55.1 \mathrm{bcD}$ & $63.4 \mathrm{aBC}$ & $51.1 \mathrm{bE}$ & $65.9 \mathrm{bAB}$ & $62.3 \mathrm{bC}$ & $68.7 \mathrm{aA}$ \\
\hline CF 101 & 55.2 & $51.1 \mathrm{aD}$ & $35.3 \mathrm{cF}$ & $63.4 \mathrm{aB}$ & $43.2 \mathrm{bE}$ & $53.1 \mathrm{cdD}$ & $56.5 \mathrm{bC}$ & $51.6 \mathrm{abD}$ & $69.6 \mathrm{aA}$ & $60.5 \mathrm{bB}$ & $67.8 \mathrm{aA}$ \\
\hline HELIO 250 & 48.8 & $41.7 \mathrm{cE}$ & $30.4 \mathrm{dG}$ & $54.6 \mathrm{cBC}$ & $35.2 \mathrm{cF}$ & $53.1 \mathrm{cdBC}$ & $52.4 \mathrm{cC}$ & $45.6 \mathrm{cD}$ & $65.6 \mathrm{bA}$ & $52.4 \mathrm{cC}$ & $56.5 \mathrm{cB}$ \\
\hline HELIO 251 & 49.5 & $42.5 \mathrm{bcF}$ & $35.2 \mathrm{cG}$ & $54.0 \mathrm{cBC}$ & $43.2 \mathrm{bEF}$ & $50.9 \mathrm{dC}$ & $47.3 \mathrm{dD}$ & $46.1 \mathrm{cDE}$ & $60.2 \mathrm{cA}$ & $55.4 \mathrm{cB}$ & $60.4 \mathrm{bA}$ \\
\hline Mean & & 45.2 & 36.7 & 59.2 & 42.3 & 55.0 & 55.7 & 50.2 & 67.1 & 58.5 & 65.1 \\
\hline \multicolumn{12}{|l|}{$C 18: 2 \Delta^{9.12}(\%)$} \\
\hline Aguara 04 & 37.5 & $50.7 \mathrm{aA}$ & $51.3 \mathrm{dA}$ & $32.8 \mathrm{bE}$ & $44.0 \mathrm{cB}$ & $32.5 \mathrm{cE}$ & $35.7 \mathrm{cDE}$ & $40.0 \mathrm{bcC}$ & $23.7 \mathrm{bcF}$ & $38.6 \mathrm{aCD}$ & $25.8 \mathrm{cF}$ \\
\hline Aguará 06 & 36.4 & $47.3 \mathrm{bC}$ & $51.1 \mathrm{~dB}$ & $32.7 \mathrm{bEF}$ & $58.2 \mathrm{aA}$ & $31.2 \mathrm{cF}$ & $35.5 \mathrm{cDE}$ & $37.6 \mathrm{cD}$ & $21.0 \mathrm{cH}$ & $25.5 \mathrm{cG}$ & $23.4 \mathrm{cGH}$ \\
\hline BRS 323 & 35.1 & $42.3 \mathrm{cB}$ & $53.7 \mathrm{cdA}$ & $29.1 \mathrm{cDE}$ & $41.5 \mathrm{cB}$ & $35.9 \mathrm{bC}$ & $29.0 \mathrm{dDE}$ & $40.3 \mathrm{bcB}$ & $26.1 \mathrm{bEF}$ & $30.1 \mathrm{bD}$ & $23.4 \mathrm{cF}$ \\
\hline CF 101 & 37.5 & $41.7 \mathrm{cC}$ & $56.7 \mathrm{bA}$ & $29.9 \mathrm{bcE}$ & $49.5 \mathrm{bB}$ & $38.8 \mathrm{abCD}$ & $36.3 \mathrm{cD}$ & $40.9 \mathrm{bC}$ & $23.5 \mathrm{bcF}$ & $32.7 \mathrm{bE}$ & $25.4 \mathrm{cF}$ \\
\hline HELIO 250 & 43.1 & $49.9 \mathrm{abC}$ & $61.1 \mathrm{aA}$ & $37.5 \mathrm{aEF}$ & $56.5 \mathrm{aB}$ & $38.7 \mathrm{abEF}$ & $39.8 \mathrm{bE}$ & $46.0 \mathrm{aD}$ & $26.5 \mathrm{bG}$ & $39.6 \mathrm{aE}$ & $35.8 \mathrm{aF}$ \\
\hline HELIO 251 & 42.3 & $48.8 \mathrm{abB}$ & $55.8 \mathrm{bcA}$ & $38.3 \mathrm{aEF}$ & $48.4 \mathrm{bBC}$ & $41.0 \mathrm{aE}$ & $44.6 \mathrm{aD}$ & $45.1 \mathrm{aCD}$ & $31.9 \mathrm{aG}$ & $36.7 \mathrm{aF}$ & $31.9 \mathrm{bG}$ \\
\hline Mean & & 46.8 & 54.9 & 33.4 & 49.7 & 36.3 & 36.8 & 41.7 & 25.5 & 33.9 & 27.6 \\
\hline
\end{tabular}

Note. ${ }^{1}$ Means followed by the same lowercase letter in the same column and means followed by the same uppercase letter in the same row do not differ from each other by Tukey's test at $5 \%$ probability.

Minimum temperature was the main factor influencing the variation of fatty acid contents in the semi-arid region (Table 3). However, the mean oleic acid content obtained in Poço Redondo (Sergipe-SE) (2014), where the minimum temperature was $19.5^{\circ} \mathrm{C}$, was $59.2 \%$, which was similar to that found in Teresina (Piauí-PI) (2015), 
where the minimum temperature reached $23.2^{\circ} \mathrm{C}$. Moreover, the Poço Redondo $\left(09^{\circ} 48^{\prime} 18^{\prime \prime} \mathrm{S}\right)$ and Frei Paulo $\left(10^{\circ} 32^{\prime} 58^{\prime \prime} \mathrm{S}\right)$ sites, both in the State of Sergipe, present similar latitudes and minimum temperatures (difference of less than $1{ }^{\circ} \mathrm{C}$ ), but the oleic acid content in Frei Paulo was lower-only 45.2\%. This result differs from that reported by Grunvald et al. (2013) in a genotype evaluation study in the tropical region of Brazil, wherein similar fatty acid profiles were obtained from environments at similar latitudes, despite differences in minimum temperatures. Thus, latitude and minimum temperature cannot explain the fatty acid profile obtained in Poço Redondo, which was likely affected by additional factors.

Although Poço Redondo (SE) and Frei Paulo (SE) belong to the semi-arid region and are located at similar latitudes, the former site is located in a region called Sertão and the latter in the Agreste, which tends to present greater rainfall than the Sertão. Except for Poço Redondo (SE), the three sites (Frei Paulo, SE, Cruz das Almas, Bahia-BA and Alagoa Nova, Paraíba-PB) with lower minimum temperatures (between 18.8 and $21^{\circ} \mathrm{C}$ ) showed the lowest oleic acid contents $(45.2 \%, 36.8 \%$ and $42.3 \%$, respectively) in sunflower achene oil and are located either in the Agreste or in an adjacent region. Similar to Poço Redondo and Frei Paulo, Jaíba (Sertão) and Alagoa Nova (Agreste) presented similar minimum temperatures (equal or close to $21{ }^{\circ} \mathrm{C}$ ) but different oleic acid contents (55.7\% and $42.3 \%$, respectively).

Sunflower plants' demand for water after flowering can reach 6 to $8 \mathrm{~mm}$ per day (Castro \& Farias, 2005). Rainfall after flowering of the genotypes cultivated in Poço Redondo and Jaíba reached less than $60 \mathrm{~mm}$-water stress was avoided by irrigating the field experiments. Hence, some factor-other than water stress - must have accounted for the differences in fatty acid profiles between Frei Paulo (Agreste) and Poço Redondo (Sertão) and between Alagoa Nova (Agreste) and Jaíba (Sertão), environments that exhibited similar minimum temperatures. Flagella et al. (2002) reported that irrigation may reduce the oleic/linoleic acid ratio, possibly by affecting the oleate desaturase enzymatic activity during achene development. However, irrigation in the Poço Redondo and Jaíba experimental sites did not reduce this ratio.

In the present work, significant differences between genotypes were observed in all environments. In each experimental site, there was a tendency for the Aguara 04, Aguará 06, BRS 323 and CF 101 hybrids to present higher oleic acid contents (mean difference of approximately 7\%) and, thus, lower linoleic acid contents than the HELIO 250 and HELIO 251 genotypes.

\subsection{Palmitic and Stearic Acids}

As described above for oleic and linoleic acids, the differences in palmitic and stearic acid contents between genotypes were analyzed in each environment (specific site and year), and the environmental effect was evaluated for each genotype (Tables 2 and 4). Palmitic acid contents varied between 3.3\% for the CF 101 hybrid in Poço Redondo (2014) and 5.6\% for hybrid HELIO 251 in Cruz das Almas (2015). Stearic acid levels ranged between 2.4\% for the Aguará 4 hybrid in Cruz das Almas (2015) and 4.2\% for the Aguará 6 hybrid in Alagoa Nova (2016) (Table 4). Genotypes showed a trend of higher palmitic acid levels in Cruz das Almas (2015, minimum temperature of $19.2^{\circ} \mathrm{C}$ ) and Jaíba $\left(2015\right.$ and $\left.21.5^{\circ} \mathrm{C}\right)$, and lower levels in Poço Redondo $(2014$ and $19.5^{\circ} \mathrm{C}$ ), Mata Roma $\left(2014\right.$ and $26^{\circ} \mathrm{C}$ ) and Magalhães de Almeida $\left(2014\right.$ and $\left.23{ }^{\circ} \mathrm{C}\right)$. Genotypes generally had higher stearic acid levels in Alagoa Nova $\left(2016\right.$ and $21^{\circ} \mathrm{C}$ ) and São João do Piauí $\left(2014\right.$ and $\left.22.5^{\circ} \mathrm{C}\right)$ and lower levels in Cruz das Almas $\left(2015\right.$ and $\left.19.3^{\circ} \mathrm{C}\right)$ and Teresina $\left(2015\right.$ and $\left.23.5^{\circ} \mathrm{C}\right)$.

The effect of the minimum temperature on the formation of palmitic and stearic acids was smaller than in the formation of oleic and linoleic acids (Tables 3 and 4). However, with the exception of Poço Redondo $\left(19^{\circ} \mathrm{C}\right)$ for palmitic acid and Cruz das Almas $\left(19^{\circ} \mathrm{C}\right)$ for stearic acid, higher minimum temperatures tended to yield reduced contents of both acids. That trend is similar to that observed by Izquierdo and Aguirrezábal (2008) but differs from the results reported for the tropical region of Brazil by Grunvald et al. (2013), who did not find differences in palmitic and stearic acid contents, even with minimum temperature differences of $9{ }^{\circ} \mathrm{C}$.

Although an increase of minimum temperature favored a decrease of saturated acid contents, this trend was genotype-dependent. It was more clearly observed on the palmitic acid content of the Aguará 6 hybrid and the stearic acid content of the BRS 323 hybrid than on the palmitic acid content of the BRS 323 hybrid and the stearic acid content of the HELIO 251 hybrid. 
Table 4. Palmitic (C16:0) and stearic (C18:0) acid contents of sunflower achene oil obtained from experiments conducted in the Brazilian semi-arid region

\begin{tabular}{|c|c|c|c|c|c|c|c|c|c|c|c|}
\hline $\begin{array}{l}\text { Genotype/ } \\
\text { Environment }\end{array}$ & Mean & $\begin{array}{l}\text { Frei Paulo } \\
\text { (SE) } \\
2015\end{array}$ & $\begin{array}{l}\text { Cruz das } \\
\text { Almas } \\
\text { (BA) } \\
2015\end{array}$ & $\begin{array}{l}\text { Poço } \\
\text { Redondo } \\
\text { (SE) } \\
2014\end{array}$ & $\begin{array}{l}\text { Alagoa } \\
\text { Nova } \\
(\mathrm{PB}) \\
2016\end{array}$ & $\begin{array}{l}\text { Jaíba } \\
(\mathrm{MG}) \\
2015\end{array}$ & $\begin{array}{l}\text { Bom Jesus } \\
\text { da Lapa } \\
\text { (BA) } \\
2014\end{array}$ & $\begin{array}{l}\text { São João } \\
\text { do Piauí } \\
\text { (PI) } \\
2014\end{array}$ & $\begin{array}{l}\text { Magalhães } \\
\text { de Almeida } \\
\text { (MA) } \\
(2014)\end{array}$ & $\begin{array}{l}\text { Teresina } \\
(\mathrm{PI}) \\
2015\end{array}$ & $\begin{array}{l}\text { Mata Roma } \\
\text { (MA) } \\
2014\end{array}$ \\
\hline \multicolumn{12}{|l|}{ C16:0 (\%) } \\
\hline Aguara 04 & 4.1 & $4.3 \mathrm{bBC}^{1}$ & $4.7 \mathrm{cA}$ & $3.6 \mathrm{bcE}$ & $3.8 \mathrm{dDE}$ & $4.5 \mathrm{cAB}$ & $3.9^{2 /} \mathrm{bDE}$ & $4.1 \mathrm{cCD}$ & $3.6 \mathrm{bE}$ & $4.8 \mathrm{aA}$ & $3.7 \mathrm{bE}$ \\
\hline Aguará 06 & 4.0 & $4.1 \mathrm{bBCD}$ & $5.0 \mathrm{bA}$ & $3.7 \mathrm{bEFG}$ & $4.3 \mathrm{abBC}$ & $4.4 \mathrm{cB}$ & $3.9 \mathrm{bDEF}$ & $4.0 \mathrm{cCDE}$ & $3.5 \mathrm{bG}$ & $3.9 \mathrm{cDEFG}$ & $3.6 \mathrm{bFG}$ \\
\hline BRS 323 & 4.3 & $4.2 \mathrm{bBC}$ & $5.0 \mathrm{bA}$ & $3.7 \mathrm{bD}$ & $4.0 \mathrm{bcC}$ & $5.1 \mathrm{aA}$ & $4.0 \mathrm{bC}$ & $4.5 \mathrm{bB}$ & $4.4 \mathrm{aB}$ & $4.4 \mathrm{bB}$ & $4.1 \mathrm{aBC}$ \\
\hline CF 101 & 3.9 & $3.8 \mathrm{bcCDE}$ & $5.0 \mathrm{bcA}$ & $3.3 \mathrm{cF}$ & $3.7 \mathrm{dCDE}$ & $4.3 \mathrm{cB}$ & $3.8 \mathrm{bCD}$ & $4.0 \mathrm{cBC}$ & $3.6 \mathrm{bDEF}$ & $3.9 \mathrm{cCD}$ & $3.5 \mathrm{bEF}$ \\
\hline HELIO 250 & 4.5 & $4.3 \mathrm{aDE}$ & $5.4 \mathrm{aA}$ & $4.1 \mathrm{aE}$ & $4.5 \mathrm{aBCD}$ & $4.6 \mathrm{bcBCD}$ & $4.4 \mathrm{aCDE}$ & $4.7 \mathrm{abBC}$ & $4.1 \mathrm{aE}$ & $4.7 \mathrm{aB}$ & $4.3 \mathrm{aDE}$ \\
\hline HELIO 251 & 4.6 & $4.8 \mathrm{aBC}$ & $5.6 \mathrm{aA}$ & $4.1 \mathrm{aE}$ & $4.5 \mathrm{aCD}$ & $4.8 \mathrm{abB}$ & $4.6 \mathrm{aBCD}$ & $4.9 \mathrm{aB}$ & $4.3 \mathrm{aDE}$ & $4.6 \mathrm{abBCD}$ & $4.1 \mathrm{aE}$ \\
\hline Mean & & 4.2 & 5.1 & 3.8 & 4.1 & 4.6 & 4.1 & 4.3 & 3.9 & 4.4 & 3.9 \\
\hline \multicolumn{12}{|l|}{ C18:0 (\%) } \\
\hline Aguara 04 & 3.0 & $2.9 \mathrm{cAB}$ & $2.4 \mathrm{bE}$ & $2.9 \mathrm{bAB}$ & $3.2 \mathrm{cdA}$ & $3.6 \mathrm{aAB}$ & $2.7 \mathrm{bCD}$ & $3.0 \mathrm{dA}$ & $3.0 \mathrm{bBC}$ & $3.4 \mathrm{aDE}$ & $2.7 \mathrm{cCD}$ \\
\hline Aguará 06 & 3.4 & $3.3 \mathrm{abcBC}$ & $3.0 \mathrm{aC}$ & $3.6 \mathrm{aB}$ & $4.2 \mathrm{aA}$ & $3.5 \mathrm{aB}$ & $3.2 \mathrm{aBC}$ & $3.7 \mathrm{abAB}$ & $3.4 \mathrm{abBC}$ & $3.0 \mathrm{abC}$ & $2.9 \mathrm{bcC}$ \\
\hline BRS 323 & 3.4 & $3.6 \mathrm{aAB}$ & $3.2 \mathrm{aBC}$ & $3.6 \mathrm{aAB}$ & $3.6 \mathrm{bcAB}$ & $3.6 \mathrm{aAB}$ & $3.3 \mathrm{aBC}$ & $3.9 \mathrm{aA}$ & $3.3 \mathrm{abBC}$ & $3.0 \mathrm{abC}$ & $3.4 \mathrm{aBC}$ \\
\hline CF 101 & 3.0 & $3.1 \mathrm{bcABC}$ & $2.6 \mathrm{bD}$ & $3.1 \mathrm{bABC}$ & $3.0 \mathrm{dBCD}$ & $3.5 \mathrm{aA}$ & $3.0 \mathrm{abBCD}$ & $3.2 \mathrm{cdAB}$ & $3.0 \mathrm{bBCD}$ & $2.7 \mathrm{bCD}$ & $3.1 \mathrm{abcABC}$ \\
\hline HELIO 250 & 3.3 & $3.7 \mathrm{abA}$ & $2.8 \mathrm{abD}$ & $3.5 \mathrm{aAB}$ & $3.6 \mathrm{bcAB}$ & $3.4 \mathrm{abABC}$ & $3.2 \mathrm{aABCD}$ & $3.4 \mathrm{bcABC}$ & $3.5 \mathrm{aAB}$ & $3.0 \mathrm{abCD}$ & $3.1 \mathrm{abcBCD}$ \\
\hline HELIO 251 & 3.3 & $3.4 \mathrm{aABC}$ & $3.1 \mathrm{aBC}$ & $3.3 \mathrm{abABC}$ & $3.7 \mathrm{bA}$ & $3.0 \mathrm{bC}$ & $3.3 \mathrm{aABC}$ & $3.6 \mathrm{abcAB}$ & $3.3 \mathrm{abABC}$ & $3.0 \mathrm{abC}$ & $3.3 \mathrm{abABC}$ \\
\hline Mean & & 3.3 & & 3.3 & 3.5 & 3.4 & 3.1 & 3.5 & 3.3 & 3.0 & 3.1 \\
\hline
\end{tabular}

Note. ${ }^{1}$ Means followed by the same lowercase letter in the same column and means followed by the same uppercase letter in the same row do not differ from each other by Tukey's test at $5 \%$ probability.

The genotype also influenced the contents of palmitic and stearic acids. The highest contents of palmitic acid were generally obtained for the HELIO 250 and HELIO 251 hybrids, while the CF 101 and Aguara 4 hybrids exhibited the lowest levels. For stearic acid, the highest levels were generally obtained for the hybrids Aguara 6 , BRS 323, HELIO 250 and HELIO 251, and the lowest levels for the Aguará 4 and CF 101 hybrids.

\section{Conclusions}

Fatty acid profiles of sunflower achene oil cultivated in the Brazilian semi-arid region were influenced by the minimum temperature during the oil synthesis stage. An approximate $5^{\circ} \mathrm{C}$ increase in the minimum temperature yielded a $22.6 \%$ increase and a $21.9 \%$ decrease in average oleic acid and linoleic acid contents, respectively. The palmitic and stearic acids content tended to decrease as the minimum temperature increased.

\section{Acknowledgements}

CNPq (Brazilian National Council for Scientific and Technological Development) for fellowships.

\section{References}

Canvin, D. T. (1965). The effect of temperature on the oil content and fatty acid composition of the oils from several oilseed crops. Canadian Journal of Botany, 43, 63-69. https://doi.org/10.1139/b65-008

Carvalho, C. G. P. de, Silva, M. F. da, Mandarino, J. M. G., Grunvald, A. K., Ramos, N. P., Ribeiro, J. L., \& Godinho, V. de P. C. (2018). Fatty acid profiles in sunflower grains during storage in different environments. Journal of the American Oil Chemists' Society, 95, 61-67. https://doi.org/10.1002/aocs.12007

Carvalho, H. W. L. de, Carvalho, L. M. de, Carvalho, C. G. P. de, Marques, M. G., \& Porto, E. S. (2016). Avaliação do comportamento de genótipos de girassol em Sergipe no ano agrícola 2013: Boletim de pesquisa \& desenvolvimento 110. Aracaju, SE: Embrapa Tabuleiros Costeiros.

Castro, C., \& Farias, J. R. B. (2005). Ecofisiologia do girassol. In R. M. V. B. Leite, A. M. Brighenthi, \& C. Castro (Eds.), Girassol no Brasil (pp. 163-218). Londrina, PR: Embrapa Soja.

Farvid, M. S., Ding, M., Pan, A., Sun, Q., Chiuve, S. E., Steffen, L. M., ... Hu, F. B. (2014). Dietary linoleic acid and risk of coronary heart disease: A systematic review and meta-analysis of prospective cohort studies. Circulation, 130, 1568-78. https://doi.org/10.1161/CIRCULATIONAHA.114.010236

Ferreira, D. F. (2011). Sisvar: A computer statistical analysis system. Ciência e Agrotecnologia, 35, 1039-1042. https://doi.org/10.1590/S1413-70542011000600001 
Firestone, D. (2013). Official methods and recommended practices of the AOCS (6th ed.). Urbana, IL: AOCS International.

Flagella, Z., Rotunno, T., Tarantino, E., Caterina, R. D., \& Caro, A. D. (2002). Changes in seed yield and oil fatty acid composition of high oleic sunflower (Helianthus annuus L.) hybrids in relation to the sowing date and the water regime. European Journal of Agronomy, 17, 221-230. https://doi.org/10.1002/jsfa.2740510103

Gomes, P. F. (1985). Curso de estatística experimental. São Paulo, SP: Nobel.

Grunvald, A. K., Carvalho, C. G. P. de, Leite, R. S., Mandarino, J. M. G., Andrade, C. A. B., Amabile, R. F., \& Godinho, V. P. C. (2013). Influence of temperature on the fatty acid composition of the oil from sunflower genotypes grown in tropical regions. Journal of the American Oil Chemists' Society, 90, 545-553. https://doi.org/10.1007/s11746-012-2188-6

Harris, H. C., McWilliam, J. R., \& Mason, W. K. (1978). Influence of temperature on oil content and composition of sunflower seed. Australian Journal of Agricultural Research, 29, 1203-1212. https://doi.org/ 10.1071/AR9781203

Izquierdo, N. G., \& Aguirrezábal, L. A. N. (2008). Genetic variability in response of fatty acid composition to minimum night temperature during grain filling in sunflower. Field Crops Research, 106, 116-125. https://doi.org/10.1016/j.fcr.2007.10.016

Lacerda, F. F., Nobre, P., Sobral, M. C., Lopes, G. M. B., Chou, S. C., Assad, E. D., \& Brito, E. (2015). Long-term temperature and rainfall trends over northeast Brazil and Cape Verde. Journal of Earth Science and Climatic Change, 6, 2-8. https://doi.org/10.4172/2157-7617.10000296

Lajara, J., Díaz, U., \& Quidiello, R. D. (1990). Definite influence of location and climatic conditions on the fatty acid composition of sunflower seed oil. Journal of the American Oil Chemists' Society, 67, 618-623. https://doi.org/10.1007/BF02540410

Leite, R. M. V. B. C., Brighenti, A. M., \& de Castro, C. (2005). Girassol no Brasil. Londrina, PR: Embrapa Soja.

Marengo, J. A., Ambrizzi, T., Rocha, R. P. da, Alves, L. M., Cuadra, S. V., Valverde, M. C., ... Ferraz, S. E. T. (2010). Future change of climate in South America in the late twenty-first century: Intercomparison of scenarios from three regional climate models. Climate Dynamics, 35, 1073-1097. https://doi.org/10.1002/ joc. 1863

Miller, J. F., Zimmerman, D. C., \& Vick, B. A. (1987). Genetic control of high oleic acid content in sunflower oil. Crop Science, 27, 923-926. https://doi.org/10.2135/cropsci1987.0011183X002700050019x

Nasopoulou, C., \& Zabetakis, I. (2012). Benefits of fish oil replacement by plant originated oils in compounded fish feeds. A review. Food Science and Technology, 47, 217-224. https://doi.org/10.1016/j.lwt.2012.01.018

Neto, A. R., Miguel, A. M. R. de O., Mourad, A. L., Henriques, E. A., \& Alves, R. M. V. (2016). Environmental effect on sunflower oil quality. Crop Breeding and Applied Biotechnology, 16, 197-204. https://doi.org/ 10.1590/1984-70332016v16n3a30

Perdomo, L., Otero, N. B. Y. F., Escribano, Ó., Díaz-Castroverde, S., Gómez-Hernández, A., \& Benito, M. (2015). Protective role of oleic acid against cardiovascular insulin resistance and in the early and late cellular atherosclerotic process. Cardiovascular Diabetology, 14, 75. https://doi.org/10.1186/s12933015-0237-9

Van der Merwe, R., Labuschagne, M. T., Herselman, L., \& Hugo, A. (2013). Stability of seed oil quality traits in high and mid-oleic acid sunflower hybrids. Euphytica, 93, 157-168. https://doi.org/10.1007/s10681-0130888-0

Vannozzi, G. P. (2006). The perspectives of use of high oleic sunflower for oleochemistry and energy raws. Helia, 29, 1-24. https://doi.org/10.2298/HEL0644001V

\section{Copyrights}

Copyright for this article is retained by the author (s), with first publication rights granted to the journal.

This is an open-access article distributed under the terms and conditions of the Creative Commons Attribution license (http://creativecommons.org/licenses/by/4.0/). 